\title{
Editorial: Internet use and disability
}

\author{
Martin Molin \& Emma Sorbring
}

Centre for Child and Youth Studies, University West, Sweden

Dear researchers, colleagues, and those interested in research on Internet use and disability,

In recent decades there has been a remarkable societal development with regard to Internet use in different settings. Several reports highlight the increased use of digital devices in school, at home, at work, in leisure time etc. Certain issues have been raised in relation to individuals and specific groups. However, the disability perspective on this matter has been paid less attention in current research. How do people with different kinds of disabilities (e.g. physical, intellectual or mental disabilities) use the Internet? What accessibility aspects may affect user involvement on the Internet? Which risks and opportunities emerge? In this special issue we have encouraged scholars to highlight new disability research that examines the implications of increased Internet usage. There is a broad approach to different issues such as the digital divide, accessibility and participation, social vulnerability and victimization, identity and user perspectives.

Internet use and disability is a field that often involves some kind of relation between, for instance, professionals and care users, teachers and students, adults and children etc. Consequently, this fact urges us to be aware of the paradoxical situation in that we can notice an increased frequency of Internet related problems (cyberbullying, vulnerability and victimization) on the one hand, but on the other hand, the Internet provides great opportunities for receiving help and support, building new friendships, maintaining or enforcing recognition for certain categorical group rights, etc. This special issue does not claim to cover all possible aspects. The eleven contributions within this issue intend rather to act as examples and illustrations of worldwide research within the given topic. Several papers come from northern Europe (mainly the UK and Scandinavia) and North America. One contribution has its origins in Australia. We have categorised the papers in this special issue according to three themes, namely Accessibility - risks and opportunities, Vulnerability and victimization and Identity and user perspectives.

\section{The Papers in This Issue}

Five papers concern the theme of Accessibility - risks and opportunities. In a Canadian theoretical paper LussierDesrochers and colleagues discuss prerequisites to promote equal citizen participation. A model is put forward in order to identify and illustrate the dimensions that must be taken into account to promote the digital participation of people with intellectual disabilities (ID). In a literature review, the paper illustrates how dimensions like sensorimotor, cognitive and technical abilities, access to technological devices and codes and conventions interact with one another. This model, which also includes personal and environmental factors, was intended as a first step in better understanding the issues associated with social participation in the digital society. In another literature review, UK researchers Seale and Chadwick elaborate on the complex relationship between adolescents and adults with intellectual and developmental disabilities (IDD) and those providing support: how is access to and use of the Internet negotiated and how do perceptions regarding risk and normalcy mediate this negotiation? The authors also discuss methodological and conceptual approaches in 
relation to these questions. One conclusion is that methodological approaches to research in the field need to include narratives from both people with IDD and their support workers. Conceptualizations of risk and Internet use need to be problematized and re-examined in the context of the lives that people with IDD want to live. Swedish researchers Sorbring and colleagues investigate how the parents of young people with ID perceive barriers to and support for Internet participation. Based on empirical material from interviews with 22 parents, the authors bring into focus how the respondents handle support and responsibility in order to surmount barriers, rather than avoiding or ignoring them. Using a thematic analysis the authors describe parents' views as double-edged; on the one hand, they perceive great possibilities, especially when it comes to participation in social life. On the other hand, they experience difficulties and barriers for young people with ID to participate digitally in society in general. Therefore, parental support perceptions can be an important prerequisite for Internet participation.

Another two papers concern disability perspectives on accessibility and Internet use. Scholz and colleagues have analysed data from 27 European countries (Eurobarometer Opinion Survey Series 2012) to explore and model, statistically, the interaction between Internet access, disability status, age, gender, education, household financial situation and household composition. A multilevel analysis showed that socio-demographic factors can explain much of the variance in outcomes, but there is also a distinctive disability effect. Especially financial constraints, aging, and living alone are exacerbated among people with disabilities. The authors conclude that people with disabilities are over-represented in the group who are still excluded from "the digital revolution". Accessible technologies and appropriate supportive relationships are needed to address and strengthen digital participation. In the next paper, Giannoumis and colleagues discuss the paradoxical issue of web accessibility in light of, on the one hand, The United Nations Convention on the Rights of Persons with Disabilities. But on the other hand, copyright laws and policy sometimes pose challenges to realizing full and equal access to the web for persons with varying physical, mental, and cognitive disabilities. The use of technological protection measures (TPM) is put forward as an example of this. Using the example of a case study from U.S. law and policy, the paper argues that the Marrakesh Treaty can act as a bridge between the copyright and human rights regimes. This can promote the meaningful participation of persons with cognitive and other disabilities.

Three papers deal with questions connected to Vulnerability and victimization. In a U.S. questionnaire study with $1286^{\text {th }}$ through $8^{\text {th }}$ graders, Wright investigated parental mediation of technology use among adolescents with autism spectrum disorders (ASD), with a focus on the buffering effect of parental mediation on the associations between cyber-victimization and depression, anxiety, and loneliness. The findings revealed that high levels of perceived parental technology mediation made the relationship between cyber-victimization and depression more negative, while lower levels of perceived parental technology mediation made the association more positive. Furthermore, in a Canadian qualitative and exploratory study Sallafranque-St-Luis and Normand examine how people with ID or ASD use the Internet. Based on questionnaires and interviews with seven participants the results showed distressing experiences including: being insulted online, having false rumours spread, receiving threats or being targets of sexual cyber-solicitation. Users with ID have had to rely on friends, parents or social workers to avoid or rectify cyber-victimization episodes. The authors conclude that Internet access has opened a large window of opportunity for people with ID and ASD, but more education and support is needed to ensure safe and positive Internet use by this population. The third paper on the theme Vulnerability and victimization is titled "Challenges Facing Online Research: Experiences from Research Concerning CyberVictimisation of People with Disabilities". Here Alhaboby and colleagues discuss methodological challenges and implications of using online methods when exploring the impact of cyber-victimisation on people coping with disabilities and chronic conditions. The authors' draw upon a UK-based study adopting a mixed-methods design via an online-survey followed by in-depth interviews of victims. The methodological challenges were theorised from the perspective of Social Identity Theory.

Finally, another three papers concern issues on Identity and user perspectives. In an Australian study Darragh and colleagues investigate how people with ID engage with online social media and form intimate relationships. With an interpretative phenomenological approach the authors have interviewed 30 adults with ID. In contrast to other studies regarding online victimization, this paper revealed that people with ID exercised cyber safe practices without any explicit formal education and conducted themselves in a respectful manner. Few participants acted in a manner that appeared to put them at risk of exploitation. Then a Swedish paper entitled "Signs of Aphasia" follows, in which Taubner and colleagues report experiences from qualitative interviews and online observations of nine individuals with post-stroke aphasia. Based on Goffman's theory of stigma the 
authors discuss how the multimodality of the Internet enabled the participants to manage their stigma in a variety of ways and to choose whether to be perceived as persons with aphasia or not. The last paper in this special issue places a focus on how computers can be used in therapy for people with ID. In a UK study Vereenooghe and colleagues have conducted in-depth interviews with both clinicians who had experience of working with people with ID and with adults with ID who have experienced computerised training in cognitive behaviour therapy skills. The paper concludes that computer technologies open up possibilities for psychological therapy for people with ID by helping them overcome in-session communication difficulties and practice skills at home.

We are very glad to present these papers and hopefully they can inspire future research within the field of disability and Internet use.

Martin Molin \& Emma Sorbring

Centre for Child and Youth Studies

University West, Sweden

Guest Editors of Special Issue "Internet use and disability"

\section{Issue Content}

\section{Editorial}

Editorial: Internet Use and Disability

Martin Molin and Emma Sorbring

http://dx.doi.org/10.5817/CP2017-1-xx

\section{Articles}

Article 1:

Bridging the digital divide for people with intellectual disability

Dany Lussier-Desrochers, Claude L. Normand, Alejandro Romero-Torres, Yves Lachapelle, Valérie Godin-

Tremblay, Marie-Eve Dupont, Jeannie Roux, Laurence Pépin-Beauchesne, and Pascale Bilodeau

http://dx.doi.org/10.5817/CP2017-1-1

Article 2:

How does risk mediate the ability of adolescents and adults with intellectual and developmental disabilities to live a normal life by using the Internet?

Jane Seale and Darren Chadwick

http://dx.doi.org/10.5817/CP2017-1-2

Article 3:

"I'm a mother, but I'm also a facilitator in her every-day life": Parents' voices about barriers and support for internet participation among young people with intellectual disabilities

Emma Sorbring, Martin Molin, and Lotta Löfgren-Mårtenson

http://dx.doi.org/10.5817/CP2017-1-3

Article 4:

Internet access for disabled people: understanding socio-relational factors in Europe

Frederike Scholz, Betul Yalcin, and Mark Priestley

http://dx.doi.org/10.5817/CP2017-1-4

Article 5:

Web accessibility and technology protection measures: Harmonizing the rights of persons with cognitive disabilities and copyright protections on the web

G. Anthony Giannoumis, Molly Land, Wondwossen Beyene, and Peter Blanck

http://dx.doi.org/10.5817/CP2017-1-5 
Article 6:

Parental mediation, cyber victimization, adjustment difficulties, and adolescents with autism spectrum disorder

Michelle F. Wright

http://dx.doi.org/10.5817/CP2017-1-6

Article 7:

From solitude to solicitation: How people with intellectual disability or autism spectrum disorder use the internet

François Sallafranque-St-Louis and Claude L. Normand

http://dx.doi.org/10.5817/CP2017-1-7

Article 8:

Challenges facing online research: Experiences from research concerning cyber-victimisation of people with disabilities

Zhraa A. Alhaboby, James Barnes, Hala Evans, and Emma Short

http://dx.doi.org/10.5817/CP2017-1-8

Article 9:

Let's talk about sex: How people with intellectual disability in Australia engage with online social media and intimate relationships

Judith Darragh, Louise Reynolds, Caroline Ellison, and Michelle Bellon

http://dx.doi.org/10.5817/CP2017-1-9

Article 10:

Signs of aphasia: Online identity and stigma management in post-stroke aphasia

Helena Taubner, Malin Hallén, and Åsa Wengelin

http://dx.doi.org/10.5817/CP2017-1-10

Article 11:

Intellectual disability and computers in therapy: Views of service users and clinical psychologists

Leen Vereenooghe, Lina Gega, and Peter E Langdon

http://dx.doi.org/10.5817/CP2017-1-11

\section{About Journal}

The 'Cyberpsychology: Journal of Psychosocial Research on Cyberspace' is a web-based, peer-reviewed scholarly journal. The first peer-reviewed issue was published in September 2007. The journal is focused on social science research about cyberspace. It brings psychosocial reflections of the impact of the Internet on people and society. The journal is interdisciplinary, publishing works written by scholars of psychology, media studies, communication science, sociology, political science, nursing, ICT security, organizational psychology and also other disciplines with relevance to psychosocial aspects of cyberspace. The journal accepts original research articles, as well as theoretical studies and research meta-analyses. Proposals for special issues are also welcomed.

The journal is indexed with Web of Science (ESCI), SCOPUS, ERIH PLUS, EBSCO Academic Search Complete, the Directory of Open Access Journals and the Czech Database of Scientific Journals.

The articles in Cyberpsychology: Journal of Psychosocial Research on Cyberspace are open access articles licensed under the terms of the Creative Commons Attribution Non-Commercial License which permits unrestricted, noncommercial use, distribution and reproduction in any medium, provided the work is properly cited.

\section{Editor}

Prof. David Smahel, M.Sc. et Ph.D., Faculty of Social Studies, Masaryk University, Czech Republic

E-mail: smahel(at)fss.muni.cz 


\section{Associate Editor}

Prof. Kristian Daneback, Ph.D., University of Gothenburg, Sweden

E-mail: kristian.daneback(at)socwork.gu.se

\section{Managing Editor}

Lenka Dedkova, Ph.D., Faculty of Social Studies, Masaryk University, Czech Republic

E-mail: Idedkova(at)fss.muni.cz

\section{Guest Editors of Special Issue "Internet Use and Disability"}

Martin Molin, Centre for Child and Youth Studies, University West, Sweden

E-mail: martin.molin(at)hv.se

Emma Sorbring, Centre for Child and Youth Studies, University West, Sweden

E-mail: emma.sorbring(at)hv.se

\section{Editorial Board}

Prof. Kaveri Subrahmanyam, Ph.D., California State University, Los Angeles, USA

Prof. Herbert Hrachovec, Ph.D., University of Vienna, Austria

Prof. Dr. Micheline Frenette, Universite de Montreal, Canada

Prof. Alexander E. Voiskounsky, Ph.D., Lomonosov Moscow State University, Russia

Prof. Michael W. Ross, Ph.D., DrMedSc, MPH, MPHEd, University of Texas, Houston, USA

Prof. Petr Macek, CSc., Masaryk University, Czech Republic

Prof. Olle Findahl, World Internet Institute, Sweden

Prof. Jochen Peter, Ph.D., University of Amsterdam, Netherlands

Prof. Veronika Kalmus, Ph.D., University of Tartu, Estonia

Prof. Joshua Fogel, Ph.D., Brooklyn College of the City University of New York, USA

Prof. Gustavo S. Mesch, Ph.D., University of Haifa, Israel

Prof. Lelia Green, Ph.D., Edith Cowan University, Australia

Prof. Michel Walrave, Ph.D., University of Antwerp, Belgium

Michelle Wright, Ph.D., Masaryk University, Czech Republic

Václav Štětka, Ph.D., Charles University, Czech Republic

Andra Siibak, Ph.D., University of Tartu, Estonia

Adjunct Prof. Birgit U. Stetina, Ph.D., University of Vienna, Austria

Lukas Blinka, Ph.D., Masaryk University, Czech Republic

\section{Advisory Board}

Prof. Bente Traen, Ph.D., University of Oslo, Norway

Prof. Charles Ess, Ph.D., University of Oslo, Norway

Prof. Dr. Ilse Kryspin-Exner, University of Vienna, Austria

Prof. PhDr. Jan Jirák, Ph.D., Charles University, Czech Republic

Prof. Vasja Vehovar, Ph.D., University of Ljubljana, Slovenia

Prof. Larry D. Rosen, Ph.D., California State University, USA

Prof. Patricia M. Greenfield, Ph.D., University of California, USA

Prof. Peter K Smith, University of London, England

Prof. Nicola Döring, Ilmenau University of Technology, Germany 
Prof. Kimberly Young, Ph.D., St. Bonaventure University, USA

Prof. Jos de Haan, Ph.D., Erasmus University, Netherlands

Prof. Zbyněk Vybíral, Ph.D, Masaryk University, Czech Republic

Prof. Monica Whitty, Ph.D., University of Leicester, UK

Prof. Alistair Duff, Ph.D., Edinburgh Napier University, Scotland

Assoc. Prof. Alfred Choi, Ph.D., Nanyang Technological University, Singapore

Prof. Thurasamy Ramayah, Universiti Sains Malaysia, Malaysia

Assoc. Prof. Neil Coulson, Ph.D., The University of Nottingham, UK

Assoc. Prof. Kenneth C. C. Yang, Ph.D., University of Texas at El Paso, USA

Assoc. Prof. Sun Sun Lim, Ph.D., National University of Singapore, Singapore

Prof. Sameer Hinduja, Ph.D., Florida Atlantic University, USA

Assoc. Prof. Jana Horáková, Ph.D., Masaryk University, Czech Republic

Assoc. Prof. Radim Polčák, Ph.D., Masaryk University, Czech Republic

Assoc. Prof. Pille Pruulmann-Vengerfeldt, Ph.D., University of Tartu, Estonia

Assist. Prof. Alexander Schouten, Ph.D., Tilburg University, Netherlands

Assist. Prof. Ewa S. Callahan, Ph.D., Quinnipiac University, USA

Assist. Prof. Regina van den Eijnden, Ph.D., Utrecht University, Netherlands

Assist. Prof. Veysel Demirer, Ph.D., Süleyman Demirel Üniversitesi, Turkey

PhDr. Ing. Petr Soukup, Charles University, Czech Republic

Janis Wolak, Ph.D., University of New Hampshire, USA

Francesca Romana Seganti, Ph.D., Sapienza University of Rome, Italy

Jeff Gavin, Ph.D., University of Bath, UK

Hana Macháčková, Ph.D., Faculty of Social Studies, Masaryk University, Czech Republic

Michael Fenichel, Ph.D., New York, USA

Leslie Haddon, Ph.D., London School of Economics, UK

\section{Publisher}

Masaryk University, Faculty of Social Studies

Jostova 10, 60200 Brno

Czech Republic

\section{Publication Schedule}

Four issues per year: two regular issues (in July and December) plus two special issues (between regular issues)

\section{About Authors}

Martin Molin, Associate professor of social work at the Centre for Child and Youth Studies at University West, Sweden. His research and teaching interests relates to the area of: Participation and exclusion in upper secondary special programme for pupils with intellectual disabilities, Identification processes and adulthood, as well as, Transition between school and work-life for young people with intellectual disabilities.

Emma Sorbring, Professor of Child and youth studies and Research director for the Centre for Child and Youth Studies at University West, Sweden. Her research and teaching interests lie in the area of children, adolescents and families. Her projects focus on: Teenagers' Internet use and parental strategies, Sexual development in traditional and new settings (the Internet), Dating violence, Parental behaviour and children's adjustment, and Young people's decision-making. 